\title{
Fat reduction in the formulation of frankfurter sausages using inulin and pectin \\ Gerardo MÉNDEZ-ZAMORA ${ }^{1 *}$, José Arturo GARCÍA-MACÍAS ${ }^{1}$, Eduardo SANTELLANO-ESTRADA ${ }^{1}$, América CHÁVEZ-MARTÍNEZ1 ${ }^{1}$, Lorenzo Antonio DURÁN-MELÉNDEZ ${ }^{1}$, Ramón SILVA-VÁZQUEZ1 ${ }^{1}$ Armando QUINTERO-RAMOS²
}

\begin{abstract}
The aim of this study was to evaluate the influence of different concentrations of inulin and pectin as fat substitutes on the chemical composition, texture, and sensory acceptance of frankfurter sausages. Six treatments were evaluated to test fat replacement: control (T0); low fat control (T1); low fat with 15\% inulin (T2); low fat with 30\% inulin (T3); low fat with 7.5\% inulin and 7.5\% pectin (T4); and low fat with 15\% inulin and 15\% pectin (T5). The addition of fibers increased the yield (T3 and T5; 98.96\%), and the color parameters were slightly reduced (T3). Moisture (61.14\%) and ashes (6.96\%) of sausages with inulin and pectin were higher (T5), while shear force, hardness, fracturability, gumminess, and chewiness (T3 and T5) were slightly lower than those of the control. The addition of inulin (T2) increased the sensory acceptance of the sausages (5.75). Fat can be replaced with inulin and pectin in frankfurter sausages to produce healthy and functional products.
\end{abstract}

Keywords: fibers; texture; sensory acceptance; color; fat substitutes.

\section{Introduction}

Nowadays, obesity and cardiovascular diseases are changing food consumption habits; these changes have fostered the development of products with functional ingredients that meet the market demands for maintaining a healthy body (Jiménez-Colmenero et al., 2010a). Therefore, in recent years, these trends in health and lifestyle have been focused on reducing the consumption of animal fats (Ritzoulis et al., 2010). Therefore, the consumption of fat from meat products is associated with health problems (Muguerza et al., 2004), which has led to the reformulation of products with reduced fat content. Thus, reformulations in meat products seek to reduce fat, while maintaining product acceptance without affecting its appearance, smell, and flavor ensuring that these products can be considered functional foods, in some cases. Consequently, several scientific studies have developed and proposed meat products with minimum levels of fat. However, it is well known that the modification of this component reduces the sensory quality of the final product, mainly its texture and acceptance, but meat products can be formulated with low fat content by incorporating functional ingredients, such as dietary fibers. These ingredients cannot be digested nor absorbed in the human digestive tract (Roberfroid, 2007), and they have water binding capacity and the ability to replace functional characteristics of fat in meat products (Biswas et al., 2011).

Dietary fibers, particularly inulin and pectin, have been scarcely used in cooked meat products; however, they have the capacity to hold water, interact with fat, and provide texture; thus, they are suitable to be used as fat substitutes. Although it is known that the use of fat in emulsified products such as Frankfurt sausages may pose problems in their acceptance, it is possible that the technological properties of dietary fiber can improve their sensory characteristics (García et al., 2006; Nowak et al., 2007). The use of inulin and pectin in frankfurter sausages have not been studied extensively, but the use of these fibers to develop healthy meat products should be investigated. Therefore, the aim of this research was to evaluate the contribution and effect of inulin and pectin as fat substitutes on the chemical composition, texture, and sensory acceptability of frankfurter sausages.

\section{Materials and methods}

\subsection{Ingredients}

BENEO-ORAFTI ${ }^{\circledR}$ GR Inulin (92\% inulin, $8 \%$ glucose, fructose, and sucrose; Megafarma, S.A. de C.V., Mexico D.F.) and low methoxyl pectin (GRINDSTED PECTIN LA-410; degree of esterification 30\%; DANNOVA QUÍMICA, S.A. de C.V., Mexico D.F.) were used as fat substitutes. Meat byproducts (fat, pork, and beef) were obtained from the Meat Processing Unit of the Facultad de Zootecnia y Ecología, Universidad Autónoma de Chihuahua; the excess of fat content of the partially thawed meat was cut and separated. The meat was sliced into $1 \mathrm{~cm}^{2}$ pieces before use. Polyphosphates, nitrites, ascorbate, and condiments were purchased from the company McCormick Pesa, S.A. de C.V.

\subsection{Treatments}

Six treatments were evaluated to test fat replacement (Table 1): control (T0); low fat control (T1); low fat with $15 \%$ inulin (T2); low fat with 30\% inulin (T3); low fat with 7.5\% 
Table 1. Formulation of sausages prepared with inulin and pectin.

\begin{tabular}{|c|c|c|c|c|c|c|}
\hline \multirow{2}{*}{ Ingredients (\%) } & \multicolumn{6}{|c|}{ Treatments $^{1}$} \\
\hline & T0 & $\mathrm{T} 1$ & $\mathrm{~T} 2$ & T3 & $\mathrm{T} 4$ & T5 \\
\hline Beef & 10.98 & 10.98 & 10.98 & 10.98 & 10.98 & 10.98 \\
\hline Pork & 41.93 & 41.93 & 41.93 & 41.93 & 41.93 & 41.93 \\
\hline Ice & 20.37 & 20.37 & 20.37 & 20.37 & 20.37 & 20.37 \\
\hline Inulin & 0 & 0 & 2.92 & 5.84 & 1.46 & 2.92 \\
\hline Salt & 1.85 & 1.85 & 1.85 & 1.85 & 1.85 & 1.85 \\
\hline Polyphosphates & 0.2 & 0.2 & 0.2 & 0.2 & 0.2 & 0.2 \\
\hline Nitrites & 0.26 & 0.26 & 0.26 & 0.26 & 0.26 & 0.26 \\
\hline Sodium ascorbate & 0.05 & 0.05 & 0.05 & 0.05 & 0.05 & 0.05 \\
\hline Sausage condiment & 0.5 & 0.5 & 0.5 & 0.5 & 0.5 & 0.5 \\
\hline
\end{tabular}

${ }^{1} \mathrm{~T} 0$ : control, T1: low fat control, T2: $15.0 \%$ inulin, T3: $30.0 \%$ inulin, T4: 7.5\% inulin $+7.5 \%$ pectin, T5: $15.0 \%$ inulin $+15.0 \%$ pectin.

inulin and $7.5 \%$ pectin (T4); and lastly, low fat with $15 \%$ inulin and $15 \%$ pectin (T5). Each sample was composed of $1.5 \mathrm{~kg}$ of meat, and the analyses were performed in triplicate, in three different time periods (three blocks). Fat and meat were significantly different in the three experimental blocks (treatments).

\subsection{Preparation of sausages}

Ingredients and raw materials were added per $\mathrm{kg}$ of product (Table 1). The formulation and the process were performed according to the method proposed by Deda et al. (2007), with some modifications; it consisted of the following stages: (1) beef and pork partially thawed were chopped using a HOBART ${ }^{\circledR}$ cutter (Hobart Corporation, Model 84145; Troy, OHIO, USA) for $3 \mathrm{~min}$, and nitrites, ascorbate, and $1 / 3$ of ice were added slowly; (2) then, polyphosphates and the remaining $1 / 3$ of ice were incorporated, and the milling continued for 2 minutes; (3) next, the sausage condiment was added, and the process of emulsification continued for 2 more minutes, keeping the temperature below $1{ }^{\circ} \mathrm{C}$; (4) the partially thawed pork fat was added and milled for 2 min; (5) the starch was added along with the rest of the ice, and the milling continued for $3 \mathrm{~min}$; (6) once the meat dough was prepared, it was stuffed into $3 \mathrm{~cm}$ diameter cellulose casings using a TORREY ${ }^{\circledR}$ mill (Model M-22 R1; N.L., México) adapted with a mouthpiece, and the sausages were manually tied with a thread every $15 \mathrm{~cm}$; (7) subsequently, the sausages were cooked in a water bath (RIVAL ${ }^{\circledR} 20$ Quart, Model RO220; China) and were wrapped with a polyethylene film to prevent the washing of ingredients until they reached an internal temperature of $68^{\circ} \mathrm{C}$; the sausages were then cooled in an ice bath $\left(4{ }^{\circ} \mathrm{C}\right.$ for $\left.20 \mathrm{~min}\right)$, drained for $10 \mathrm{~min}$, and refrigerated at $4{ }^{\circ} \mathrm{C}$ in polyethylene bags until analysis. For the preparation of the treatments T2 and T3, inulin powder was added in the third step after the sausage condiment was added; finally, to prepare T4 and T5, pectin powder was incorporated in the first step, one minute before milling, and inulin was added in the third step after the condiment was added.

\subsection{Process yield (PY)}

The PY of the sausages was determined in each treatment (Equation 1). The cooked and uncooked sausages were weighed, and the process yield was calculated as follows: the weight of the cooked sausage sample divided by the weight of the uncooked sausage sample multiplied by 100 (Yang et al., 2007).

$\% \mathrm{PY}=[$ Weight of the cooked sausage/

Weight of the uncooked sausage] 100

\section{$2.5 \mathrm{pH}$}

The $\mathrm{pH}$ of the sausages in each batch was determined $24 \mathrm{~h}$ after their preparation using an Orion 3 Star puncture potentiometer (Portable pH meter MA 01915, Thermo Fisher Scientific, U.S.A.). Measurements were performed in triplicate.

\subsection{Water-holding capacity (WHC)}

The WHC of the sausages was determined using the compression method proposed by Tsai \& Ockerman (1981) and Dzudie et al. (2005) with some modifications. Approximately $0.3 \mathrm{~g}$ of sausage was placed between two filter papers and then placed between two $12 \times 12 \mathrm{~cm}$ plexiglass plates, and a force of $4.0 \mathrm{~kg}$ was applied for $20 \mathrm{~min}$. Due to the force exerted on the sample, the released liquids were impregnated in the paper, and they were considered as meat-free water; WHC was performed in triplicate, and the following Equations 2 and 3 were used:

$\%$ of free water $=\left[\left(\mathrm{I}_{\mathrm{w}}-\mathrm{F}_{\mathrm{w}}\right) / \mathrm{I}_{\mathrm{w}}\right] \times 100$

$\mathrm{WHC}=100-\%$ of free water

where $\mathrm{I}_{\mathrm{w}}$ is the initial weight of the sample $(0.3 \mathrm{~g})$ and $\mathrm{F}_{\mathrm{w}}$ is the final weight.

\subsection{Color}

Color was measured directly in the internal part of the sausages using a Minolta Chroma Meter 2002 colorimeter (CR-400/410, Konica Minolta Holdings, Inc., Tokyo, Japan) based on the $\operatorname{CIE}\left(\mathrm{L}^{*}, \mathrm{a}^{*}\right.$ and $\left.\mathrm{b}^{\star}\right)$ system; the equipment was 
calibrated before measurements. These were performed in triplicate in sections of $2.5 \mathrm{~cm}$ long and $3 \mathrm{~cm}$ diameter.

\subsection{Proximate analysis}

The proximate analysis of the sausages was performed $24 \mathrm{~h}$ after their preparation according to the AOAC (Association of Official Analytical Chemists, 1998): moisture, method 950.46; ashes, method 920.153; fat, method 985.15; and protein, Kjeldahl method 992.15. All the evaluations were performed in triplicate.

\subsection{Shear force (SF) and texture profile analysis (TPA)}

The SF and TPA were performed using a Texturometer (TA. XT2i Stable Micro Systems Serrey, England). For the SF, the Warner-Bratzler blade was adapted to texturometer (Su et al., 2000), and five central sections of each sample were used; these were standardized to $2.5 \mathrm{~cm}$ high and 3.0 diameter at a temperature of $4^{\circ} \mathrm{C}$; the conditions established for the test were: speed of $2 \mathrm{mms}^{-1}$ (pre-test), $2 \mathrm{mms}^{-1}$ (test), $10 \mathrm{mms}^{-1}$ (post-test), and a distance of $30 \mathrm{~mm}$.

The TPA was performed using six central sections, standardized as $2.5 \mathrm{~cm}$ high and $3.0 \mathrm{~cm}$ diameter at $4{ }^{\circ} \mathrm{C}$. A cylindrical piston was used to compress the sample during the two cycles of the test at $70 \%$ of the original height and a time interval of $5 \mathrm{~s}$ between the two compression cycles. Forcetime deformation curves were obtained from the conditions established in the texturometer: speed of $1.0 \mathrm{mms}^{-1}$ (pre-test), of $5.0 \mathrm{mms}^{-1}$ (test), and of $5.0 \mathrm{mms}^{-1}$ (post-test); the following parameters were quantified and defined according to Bourne (1978) and other authors (Ayo et al., 2008; Álvarez et al., 2012): hardness $(\mathrm{N})$, fracturability $(\mathrm{N})$, adhesiveness (gs), springiness $(\mathrm{mm})$, cohesiveness, gumminess $(\mathrm{N})$, and chewiness $(\mathrm{Nmm})$.

\subsection{Sensory evaluation}

An affective sensory test of attributes was conducted by measuring the level of satisfaction of 84 consumers. This process was approved by the Ethical Committee of the university. Each consumer received, in random order, two slices of each treatment sample $\left(5 \mathrm{~mm}\right.$ high at $\left.4{ }^{\circ} \mathrm{C}\right)$, which were served on plastic dishes encoded with three-digit random numbers; they evaluated the following attributes: pinkness, appearance, smell, taste, and overall acceptance; a 7-point hedonic scale anchored by $7=$ liked very much and $1=$ disliked very much was used (Anzaldúa-Morales, 1994; Meilgaard et al., 2006).

\subsection{Statistical analysis}

The variables were analyzed using a randomized complete block design with the GLM procedure (SAS Institute, 2006) and the following statistical model (Equation 4):

$\mathrm{y}_{i j}=\mu+\tau_{i}+\beta_{j}+\mathrm{e}_{i j}$

where $\mathrm{y}_{i j}=$ variables measured in the products by effect of the treatment $i$ and block $j ; \mu=$ treatments mean; $\tau_{i}=$ effect of the treatment $i ; \beta_{j}=$ effect of the block $j ; \mathrm{e}_{i j}=$ residual error. The significance level used for all statistical analyses was 5\%; the Tukey statistical test was performed to compare the means between treatments.

\section{Results and discussion}

\subsection{Process yield (PY)}

The addition of inulin and pectin showed a significant effect $(\mathrm{P}<0.05)$ on the PY of the sausages. The addition of these ingredients increased more than $98.5 \%$ of the PY. T3 had the highest PY value, while T0 and T1 had the lowest values (Table 2). A similar behavior was found by Xiong et al. (1999); they attributed their results to the capacity of gums to bind and hold water due to their ability to form hydrogen bonds with water. García-García \& Totosaus (2008) explain this behavior by the denaturation of meat proteins before gelatinization of other ingredients in the polysaccharide-meat system. On the other hand, Choi et al. (2010) reported that the yield depends on temperature, cooking time, ingredients, amount of fat in the products, and dietary fiber. Thus, the results obtained in this research indicate that dietary ingredients can improve the yield of the sausages.

\section{$3.2 \mathrm{pH}$}

The dietary ingredients used had significant effects $(\mathrm{P}<0.05)$ on the $\mathrm{pH}$ of the sausages (Table 2$)$. The $\mathrm{pH}$ decreased with increased concentration of inulin and pectin. T5 had the lowest $\mathrm{pH}$, and T0 had the highest. Xiong et al. (1999) reported that polysaccharides and proteins in food interact through electrostatic association (attraction and repulsion) between the polar and non-polar groups of gums and proteins, resulting in $\mathrm{pH}$ variations. Choi et al. (2009) obtained opposite results to those of the present study; they found higher $\mathrm{pH}$ (6.46 to 6.47) in sausages formulated with vegetable oil and rice bran fiber; these authors attributed this phenomenon to the minerals, such

Table 2. Influence of inulin and pectin on the quality of reduced-fat frankfurters.

\begin{tabular}{|c|c|c|c|c|c|c|}
\hline \multirow{2}{*}{ Treatments $^{1}$} & \multicolumn{6}{|c|}{ Parameters } \\
\hline & PY $(\%)$ & $\mathrm{pH}$ & WHC (\%) & Lightness $\left(\mathrm{L}^{*}\right)$ & Redness $\left(a^{*}\right)$ & Yellowness $\left(b^{*}\right)$ \\
\hline T0 & $97.27 \pm 0.15^{\mathrm{d}}$ & $5.86 \pm 0.03^{\mathrm{a}}$ & $68.65 \pm 0.89^{a}$ & $66.78 \pm 0.32^{\mathrm{a}}$ & $9.21 \pm 0.14^{\mathrm{b}}$ & $11.47 \pm 0.12^{c}$ \\
\hline $\mathrm{T} 1$ & $97.63 \pm 0.15^{\mathrm{cd}}$ & $5.77 \pm 0.03^{\mathrm{ab}}$ & $65.25 \pm 0.89^{\mathrm{ab}}$ & $65.18 \pm 0.32^{b c}$ & $10.08 \pm 0.14^{\mathrm{a}}$ & $11.45 \pm 0.12^{c}$ \\
\hline $\mathrm{T} 2$ & $98.49 \pm 0.15^{\mathrm{ab}}$ & $5.79 \pm 0.03^{\mathrm{ab}}$ & $62.49 \pm 0.89^{b}$ & $64.70 \pm 0.32^{\mathrm{bc}}$ & $9.98 \pm 0.14^{\mathrm{a}}$ & $11.48 \pm 0.12^{\mathrm{c}}$ \\
\hline $\mathrm{T} 3$ & $98.96 \pm 0.15^{\mathrm{a}}$ & $5.76 \pm 0.03^{\mathrm{ab}}$ & $59.43 \pm 0.89^{c}$ & $64.14 \pm 0.32^{c}$ & $9.95 \pm 0.14^{\mathrm{a}}$ & $11.43 \pm 0.12^{c}$ \\
\hline $\mathrm{T} 4$ & $98.20 \pm 0.15^{\mathrm{bc}}$ & $5.71 \pm 0.03^{b c}$ & $65.25 \pm 0.89^{\mathrm{ab}}$ & $66.65 \pm 0.32^{\mathrm{a}}$ & $9.74 \pm 0.14^{\mathrm{ab}}$ & $12.48 \pm 0.12^{b}$ \\
\hline T5 & $98.68 \pm 0.15^{\mathrm{ab}}$ & $5.57 \pm 0.03^{c}$ & $67.11 \pm 0.89^{a}$ & $65.96 \pm 0.32^{\mathrm{ab}}$ & $9.87 \pm 0.14^{\mathrm{a}}$ & $13.13 \pm 0.12^{\mathrm{a}}$ \\
\hline
\end{tabular}

${ }^{a-c}$ Means ( \pm standard error) in the same column with different letters are different $(\mathrm{P}<0.05) .{ }^{1} \mathrm{~T} 0:$ control, T1: low fat control, T2: $15.0 \%$ inulin, T3: $30.0 \%$ inulin, T4: 7.5\% inulin + $7.5 \%$ pectin, $\mathrm{T} 5: 15.0 \%$ inulin $+15.0 \%$ pectin. 
as iron, phosphorus, and calcium, present in the fibers. However, López-López et al. (2009) obtained low pH using edible algae (5\%; Himanthalia elongata) in low-fat (10\%) sausages; these authors attributed their results to low ionic strength, chemical composition of dietary fiber, and the protein content of the polysaccharides. Kim et al. (2011) stated that the decrease of $\mathrm{pH}$ in sausages is affected by the ingredients used in the formulation. In this research, the decrease in the sausage $\mathrm{pH}$ may be due to the pectin $\mathrm{pH}$ (4.3).

\subsection{WHC}

WHC was influenced $(\mathrm{P}<0.05)$ by the addition of dietary fibers to the low fat sausages (Table 2); T5 and T0 had the highest WHC, and T3 had the lowest; these results showed that the addition of $15 \%$ inulin and pectin (T5) improve the water holding capacity. Cengiz \& Gokoglu (2007) found increased WHC using citrus fiber in sausages with three fat levels (20, 10 and 5\%); they reported that this result is due to the high fat levels and addition of fiber. Therefore, the results of this research showed that the addition of pectin improves WHC. On the other hand, according to López-López et al. (2009), water holding capacity of some fibers is related to the type and amount of their polysaccharides; large particles are associated with open structures that improve the properties of hydration and fat absorption capacity. This could explain the fact that the addition of inulin and pectin increased the WHC due to their ability to bind water molecules and retain fat.

\subsection{Color}

The addition of dietary fiber had significant effect $(\mathrm{P}<0.05)$ on the color parameters of frankfurter sausages (Table 2). $\mathrm{L}^{*}$ was lower in T3 but higher in T4, which was not different from the $\mathrm{L}^{*}$ value of the control (T0). Accordingly, Cáceres et al. (2004) found similar color parameters values in sausages with fructooligosaccharides (2-12\%); they reported that these differences are due to the lack of fat and incorporation of dietary fiber. Moreover, $\mathrm{a}^{\star}$ was influenced by the addition of dietary ingredients; T2 and T3 were the highest. The $\mathrm{b}^{\star}$ value was affected by inulin and pectin. T5 and T4 showed the highest values. This indicates that an increase in pectin concentration affected $\mathrm{a}^{\star}$ and $\mathrm{b}^{\star}$ values, whereas the addition of inulin did not have the same effect. Cáceres et al. (2004) stated that the $\mathrm{a}^{*}$ and $\mathrm{b}^{*}$ values were not affected by fructooligosaccharides since they were characterized as whitish and translucent.
Similar behavior was obtained by Özvural et al. (2009) using brewery's spent grain (1, 3 and 5\%) in sausages. On the other hand, Ayo et al. (2008) highlighted that by reducing the fat content, $\mathrm{L}^{*}$ and $\mathrm{b}^{*}$ values decreased and $\mathrm{a}^{*}$ increased, but a number of variations can be found in color when the fat level and meat content (myoglobin) is changed (JiménezColmenero et al., 2010b). Therefore, the addition of pectin and inulin affects the lightness, redness, and yellowness values.

\subsection{Proximate analysis}

Significant effects $(\mathrm{P}<0.05)$ were found in moisture, fat, and ash contents, but there were no differences in the protein content (Table 3). The moisture of T5 was higher than that of T0, and T1 had the highest value. The addition of fibers increased moisture content; similar behavior was found by Vural et al. (2004), Choi et al. (2009) and Choi et al. (2010) using rice bran fiber; these authors reported that this fiber increases the water holding capacity and therefore the moisture content in the sausages. Fat level was the highest in T0 because it was formulated with the highest content of back fat (19.47\%), while the other treatments had the lowest fat content because they were formulated with 16.55 and $13.63 \%$ of back fat and dietary fibers. Tobin et al. (2012) obtained similar results in sausages; they stated that the sausages prepared with high fat levels have high fat content. The ash content was higher in all low-fat sausages due to the addition of inulin and pectin. According to López-López et al. (2009) and Choi et al. (2010), ash increased with the incorporation of algae and rice bran fiber in low-fat products. Finally, the protein content of sausages was not influenced $(\mathrm{P}>0.05)$ by the addition of inulin and pectin. Jiménez-Colmenero et al. (2010a) found similar changes in the composition of low-fat sausages prepared with konjac dietary fiber (10.5 and 19.3\%) and seaweed (3.3\%); these authors reported that this was due to the ability of dietary fiber to change the composition of the product.

\subsection{Shear force (SF) and texture profile analysis (TPA)}

The textural behavior of sausages with dietary fibers is shown in Table 4. SF of the sausages was influenced $(\mathrm{P}<0.05)$; T1 had the highest value, and T3 had the lowest. This result shows that inulin and pectin could simulate the functional characteristics of fat in sausages, especially due to the high water absorption capacity of inulin. Totosaus \& Pérez-Chabela (2009) obtained similar data in meat batters with gellan gum; they reported that reduced fat levels and the addition of gums

Table 3. Proximate composition of low-fat frankfurters with inulin and pectin.

\begin{tabular}{ccccc}
\hline \multirow{2}{*}{ Treatments $^{1}$} & \multicolumn{4}{c}{ Parameters (\%) } \\
\cline { 2 - 5 } & Moisture & Protein & Fat & Ashes \\
\hline T0 & $57.76 \pm 0.73^{\mathrm{c}}$ & $10.24 \pm 0.19$ & $17.80 \pm 0.33^{\mathrm{a}}$ & $5.88 \pm 0.18^{\mathrm{c}}$ \\
T1 & $61.90 \pm 0.73^{\mathrm{a}}$ & $10.29 \pm 0.19$ & $8.90 \pm 0.33^{\mathrm{c}}$ & $7.88 \pm 0.18^{\mathrm{a}}$ \\
T2 & $58.13 \pm 0.73^{\mathrm{bc}}$ & $10.28 \pm 0.19$ & $12.51 \pm 0.33^{\mathrm{b}}$ & $6.48 \pm 0.18^{\mathrm{bc}}$ \\
T3 & $59.87 \pm 0.73^{\mathrm{abc}}$ & $10.94 \pm 0.19$ & $9.05 \pm 0.33^{\mathrm{c}}$ & $6.35 \pm 0.18^{\mathrm{bc}}$ \\
T4 & $58.31 \pm 0.73^{\mathrm{bc}}$ & $10.96 \pm 0.19$ & $13.35 \pm 0.33^{\mathrm{b}}$ & $6.74 \pm 0.18^{\mathrm{b}}$ \\
T5 & $61.14 \pm 0.73^{\mathrm{ab}}$ & $10.43 \pm 0.19$ & $9.26 \pm 0.33^{\mathrm{c}}$ & $6.96 \pm 0.18^{\mathrm{b}}$ \\
\hline
\end{tabular}

\footnotetext{
${ }^{a-c}$ Means ( \pm standard error) in the same column with different letters are different $(\mathrm{P}<0.05) .{ }^{1} \mathrm{~T} 0:$ control, $\mathrm{T} 1:$ low fat control, T2: $15.0 \%$ inulin, T3: $30.0 \%$ inulin, T4: 7.5\% inulin +
} $7.5 \%$ pectin, $\mathrm{T} 5: 15.0 \%$ inulin $+15.0 \%$ pectin. 
in the presence of $\mathrm{Ca}^{2+}$, resulted in hard gels, which changed the textural properties (Savadkoohi et al., 2014) and therefore SF high values could be obtained. According to GonzálezViñas et al. (2004), samples with high-fat and increased dry matter resulted in lower values of SF.

The effects of replacing backfat with different levels of inulin and pectin on the textural properties of sausages are presented in Table 4. In general, the results show significant differences $(\mathrm{P}<0.05)$ in TPA. Hardness, cohesiveness, gumminess, and chewiness were lower in treatments with dietary fibers. For example, hardness was lower in T5, whereas T1 had the highest value. These differences could be attributed to the fat content and the dietary ingredients due to their high binding ability and water holding capacity (Choi et al., 2014); in the present study, the sausages with fibers were softer. According to Cierach et al. (2009), the hardness in the sausages is related to their fat content.

Fracturability was not different between the treatments $(\mathrm{P}>0.05)$; however, low fat treatments with inulin and pectin had low values (Table 4). Moreover T1, T2, and T3 had the lowest adhesion values; therefore, inulin (T3) did not affect this parameter. Pereira et al. (2011) reported that this feature should be smooth and without adhesion. T1 had the lowest adhesiveness value; this suggests that fat and dietary fibers were responsible for restructuring the sausages. An effect of inulin and pectin on the springiness of the sausages was observed; treatments T0 and T4 were more elastic (Table 4). Xiong et al. (1999) highlighted that the increase in the charges of protein allows for electrostatic interactions between proteins and polysaccharides; therefore, this facilitates the formation of more elastic gels in products. Similar results were obtained by Youssef \& Barbut (2011), who stated that texture parameters vary due to the formation of a dense protein matrix and a rigid structure depending on the amount of lean meat used in the formulation. In this study, the sausages made with inulin and pectin were not statistically different from that in the T0; this could be attributed to the ability of dietary fibers to mimic the function of fat in the sausages.

\subsection{Sensory evaluation}

Table 5 presents the acceptance of the sensory attributes of the sausages. The addition of inulin and pectin influenced $(\mathrm{P}<0.05)$ the sensory attributes. T2 was the most preferred due to its pinkness and appearance, while T3 was the least accepted. Cierach et al. (2009) reported that using carrageenan (0.41 and $0.70 \%$ ) in sausages with 10 and $20 \%$ fat, increased preference of their pinkness, juiciness, hardness, and flavor; presumably caused by the dilution of myoglobin due to some ingredients. For example, in this research, pectin and inulin improved the acceptance of some attributes such as appearance and flavor. Özvural et al. (2009) reported that the addition of powered brewery's spent grains $(1,3$, and $5 \%)$ in sausages (10\% fat) decreased palatability and sensory scores; in this study, for example, higher levels of pectin affected the flavor and odor.

Smell and hardness exhibited similar behavior in the frankfurter sausages. T1 was the most accepted and T5 was the least accepted. With regard to the flavor and overall acceptance of the low-fat sausages, T2 was the most accepted, while T5 was less accepted. Tobin et al. (2012) reported that $10 \%$ fat in

Table 4. Effects on texture attributes of low-fat frankfurters with inulin and pectin.

\begin{tabular}{|c|c|c|c|c|c|c|}
\hline \multirow{2}{*}{ Variable } & \multicolumn{6}{|c|}{ Treatments $^{1}$} \\
\hline & T0 & $\mathrm{T} 1$ & $\mathrm{~T} 2$ & T3 & $\mathrm{T} 4$ & $\mathrm{~T} 5$ \\
\hline $\mathrm{SF}\left(\mathrm{Kg}_{\mathrm{f}}\right)$ & $1.54 \pm 0.08^{\mathrm{ab}}$ & $1.59 \pm 0.08^{\mathrm{a}}$ & $1.35 \pm 0.08^{\mathrm{ab}}$ & $1.30 \pm 0.08^{\mathrm{b}}$ & $1.41 \pm 0.08^{\mathrm{ab}}$ & $1.34 \pm 0.08^{\mathrm{ab}}$ \\
\hline Hardness (N) & $86.00 \pm 4.28^{\mathrm{b}}$ & $100.66 \pm 4.28^{\mathrm{a}}$ & $79.48 \pm 4.28^{\mathrm{b}}$ & $65.55 \pm 4.28^{\mathrm{cd}}$ & $76.34 \pm 4.28^{\mathrm{bc}}$ & $61.77 \pm 4.28^{\mathrm{d}}$ \\
\hline Fracturability $(\mathrm{N})$ & $89.18 \pm 6.31$ & $91.04 \pm 8.02$ & $87.38 \pm 5.35$ & $83.56 \pm 4.74$ & $94.32 \pm 5.13$ & $77.19 \pm 4.46$ \\
\hline Adhesiveness (gs) & $-20.59 \pm 8.63^{\mathrm{ab}}$ & $-7.83 \pm 9.34^{\mathrm{a}}$ & $-5.99 \pm 10.93^{\mathrm{a}}$ & $-3.34 \pm 8.64^{\mathrm{a}}$ & $-49.93 \pm 8.69^{b}$ & $-38.24 \pm 8.39^{\mathrm{ab}}$ \\
\hline Springiness (mm) & $0.81 \pm 0.02^{\mathrm{a}}$ & $0.77 \pm 0.02^{\mathrm{ab}}$ & $0.78 \pm 0.02^{\mathrm{a}}$ & $0.76 \pm 0.02^{\mathrm{ab}}$ & $0.82 \pm 0.02^{\mathrm{a}}$ & $0.71 \pm 0.02^{b}$ \\
\hline Cohesiveness & $0.23 \pm 0.01^{\mathrm{ab}}$ & $0.25 \pm 0.01^{\mathrm{a}}$ & $0.23 \pm 0.01^{\mathrm{ab}}$ & $0.23 \pm 0.01^{\mathrm{ab}}$ & $0.22 \pm 0.01^{\mathrm{ab}}$ & $0.21 \pm 0.01^{\mathrm{b}}$ \\
\hline Gumminess (N) & $20.06 \pm 1.34^{\mathrm{b}}$ & $24.24 \pm 1.34^{\mathrm{a}}$ & $18.23 \pm 1.30^{\mathrm{bc}}$ & $15.07 \pm 1.30^{\mathrm{cd}}$ & $16.88 \pm 1.30^{\mathrm{bc}}$ & $12.74 \pm 1.30^{\mathrm{d}}$ \\
\hline Chewiness (Nmm) & $16.19 \pm 1.13^{\mathrm{b}}$ & $19.89 \pm 1.13^{\mathrm{a}}$ & $14.38 \pm 1.10^{\mathrm{bc}}$ & $11.65 \pm 1.10^{\mathrm{cd}}$ & $13.92 \pm 1.10^{\mathrm{bc}}$ & $9.01 \pm 1.10^{\mathrm{d}}$ \\
\hline
\end{tabular}

${ }^{\mathrm{a}-\mathrm{d}}$ Means ( \pm standard error) in the same column with different letters are different $(\mathrm{P}<0.05) .{ }^{1} \mathrm{~T} 0$ : control, T1: low fat control, T2: $15.0 \%$ inulin, T3: $30.0 \%$ inulin, T4: $7.5 \%$ inulin + $7.5 \%$ pectin, $\mathrm{T} 5: 15.0 \%$ inulin $+15.0 \%$ pectin.

Table 5. Sensory evaluation of low-fat frankfurters with inulin and pectin.

\begin{tabular}{|c|c|c|c|c|c|c|}
\hline \multirow{2}{*}{ Treatments $^{1}$} & \multicolumn{6}{|c|}{ Sensory attributes } \\
\hline & Pinkness & Appearance & Smell & Hardness & Flavor & Overall Acceptance \\
\hline T0 & $5.46 \pm 0.92^{\mathrm{ab}}$ & $5.63 \pm 0.90^{\mathrm{ab}}$ & $5.17 \pm 0.89^{\mathrm{ab}}$ & $5.48 \pm 0.90^{\mathrm{a}}$ & $5.37 \pm 0.98^{a}$ & $5.73 \pm 084^{\mathrm{a}}$ \\
\hline $\mathrm{T} 1$ & $5.58 \pm 1.09^{\mathrm{ab}}$ & $5.49 \pm 1.23^{\mathrm{abc}}$ & $5.33 \pm 0.91^{\mathrm{a}}$ & $5.46 \pm 0.81^{\mathrm{a}}$ & $5.39 \pm 0.82^{\mathrm{a}}$ & $5.67 \pm 0.87^{\mathrm{a}}$ \\
\hline $\mathrm{T} 2$ & $5.75 \pm 0.73^{\mathrm{a}}$ & $5.81 \pm 0.69^{\mathrm{a}}$ & $5.18 \pm 0.92^{\mathrm{ab}}$ & $5.42 \pm 0.91^{\mathrm{a}}$ & $5.46 \pm 0.91^{\mathrm{a}}$ & $5.75 \pm 0.73^{\mathrm{a}}$ \\
\hline $\mathrm{T} 3$ & $5.36 \pm 0.87^{\mathrm{b}}$ & $5.21 \pm 1.01^{\mathrm{c}}$ & $5.04 \pm 0.81^{\mathrm{abc}}$ & $4.85 \pm 1.08^{\mathrm{bc}}$ & $4.69 \pm 1.05^{\mathrm{b}}$ & $5.23 \pm 0.87^{\mathrm{b}}$ \\
\hline $\mathrm{T} 4$ & $5.42 \pm 1.03^{\mathrm{ab}}$ & $5.33 \pm 1.03^{\mathrm{bc}}$ & $4.70 \pm 1.03^{\mathrm{c}}$ & $5.19 \pm 0.96^{\mathrm{ab}}$ & $4.80 \pm 1.15^{\mathrm{b}}$ & $5.18 \pm 0.89^{b}$ \\
\hline T5 & $5.37 \pm 1.22^{\mathrm{ab}}$ & $5.56 \pm 1.07^{\mathrm{abc}}$ & $4.95 \pm 0.90^{\mathrm{bc}}$ & $4.73 \pm 1.24^{\mathrm{c}}$ & $3.98 \pm 1.25^{\mathrm{c}}$ & $4.55 \pm 1.09^{\mathrm{c}}$ \\
\hline
\end{tabular}

${ }^{\text {a-c }}$ Means ( \pm standard error) in the same column with different letters are different $(\mathrm{P}<0.05) .{ }^{1} \mathrm{~T} 0$ : control, T1: low fat control, T2: $15.0 \%$ inulin, T3: $30.0 \%$ inulin, T4: $7.5 \%$ inulin + $7.5 \%$ pectin, $\mathrm{T} 5: 15.0 \%$ inulin $+15.0 \%$ pectin. 
sausages adversely affects the juiciness, while 25 and $15 \%$ fat are positively correlated to juiciness and flavor. Similar results were obtained by Huang et al. (2011) when studying the effect of the addition of inulin (3.5 and 7.0\%) on the sensory properties of sausages; these authors suggested that the high solubility of inulin improved textural properties. Andrès et al. (2006) stated that the hydrocolloids improve product texture, notably the flavor. In the present study, T2 improved acceptance of flavor in the sausages. Similar behavior was found by Grizotto et al. (2012).

\section{Conclusions}

Inulin and pectin increased the yield and improved the color parameters associated with consumer acceptance. The proximate analysis of the sausages showed that meat products can be reformulated with fibers, preserving the protein content and the water holding capacity. The textural analysis and the sensory evaluation demonstrated that dietary fibers can be used in sausages as fat replacers and also as a source of prebiotic ingredients.

\section{References}

Álvarez, D., Xiong, Y. L., Castillo, M., Payne, F. A., \& Garrido, M. D. (2012). Textural and viscoelastic properties of pork frankfurters containing canola-olive oils, rice bran, and walnut. Meat Science, 92(1), 8-15. http://dx.doi.org/10.1016/j.meatsci.2012.03.012. PMid:22503483

Andrès, S., Zaritzky, N., \& Califano, A. (2006). The effect of whey protein concentrates and hydrocolloids on the texture and colour characteristics of chicken sausages. International Journal of Food Science \& Technology, 41(8), 954-961. http://dx.doi.org/10.1111/ j.1365-2621.2005.01152.x.

Anzaldúa-Morales, A. (1994). La evaluación sensorial de los alimentos en la teoría y la práctica. Zaragoza: Acribia.

Association of Official Analytical Chemists - AOAC. (1998). Official Methods of Analysis of Association of Official Analytical Chemists (15th ed.). Washington: AOAC International.

Ayo, J., Carballo, J., Solas, M. T., \& Jiménez-Colmenero, F. (2008). Physicochemical and sensory properties of healthier frankfurters as affected by walnut and fat content. Food Chemistry, 107(4), 15471552. http://dx.doi.org/10.1016/j.foodchem.2007.09.019.

Biswas, A. K., Kumar, V., Bhosle, S., Sahoo, J., \& Chatli, M. K. (2011). Dietary fibers as functional ingredients in meat products and their role in human health. International Journal of Livestock Production, 2(4), 45-54.

Bourne, M. C. (1978). Texture profile analysis. Food Technology, 35(2), 62-66.

Cáceres, E., García, M. L., Toro, J., \& Selgas, M. D. (2004). The effect of fructooligosaccharides on the sensory characteristics of cooked sausages. Meat Science, 68(1), 87-96. http://dx.doi.org/10.1016/j. meatsci.2004.02.008. PMid:22062011

Cengiz, E., \& Gokoglu, N. (2007). Effects of fat reduction and fat replacer addition on some quality characteristics of frankfurtertype sausages. International Journal of Food Science \& Technology, 42(3), 366-372. http://dx.doi.org/10.1111/j.1365-2621.2006.01357.x.

Choi, Y. S., Choi, J. H., Han, D. J., Kim, H. Y., Lee, M. A., Kim, H. W., Jeong, J. Y., \& Kim, C. J. (2009). Characteristics of low-fat meat emulsion systems with pork fat replaced by vegetable oils and rice bran fiber. Meat Science, 82(2), 266-271. http://dx.doi.org/10.1016/j. meatsci.2009.01.019. PMid:20416740

Choi, Y. S., Choi, J. H., Han, D. J., Kim, H. Y., Lee, M. A., Jeong, J. Y., Chung, H. J., \& Kim, C. J. (2010). Effects of replacing pork back fat with vegetable oils and rice bran fiber on the quality of reduced-fat frankfurters. Meat Science, 84(3), 557-563. http://dx.doi. org/10.1016/j.meatsci.2009.10.012. PMid:20374824

Choi, Y. S., Kim, H. W., Hwang, K. E., Song, D. H., Choi, J. H., Lee, M. A., Chung, H. J., \& Kim, C. J. (2014). Physicochemical properties and sensory characteristics of reduced-fat frankfurters with pork back fat replaced by dietary fiber extracted from makgeolli lees. Meat Science, 96(2 Pt A), 892-900. http://dx.doi.org/10.1016/j. meatsci.2013.08.033. PMid:24200582

Cierach, M., Modzelewska-Kapituła, M., \& Szaciło, K. (2009). The influence of carrageenan on the properties of low-fat frankfurters. Meat Science, 82(3), 295-299. http://dx.doi.org/10.1016/j. meatsci.2009.01.025. PMid:20416731

Deda, M. S., Bloukas, J. G., \& Fista, G. A. (2007). Effect of tomato paste and nitrite level on processing and quality characteristics of frankfurters. Meat Science, 76(3), 501-508. http://dx.doi. org/10.1016/j.meatsci.2007.01.004. PMid:22060993

Dzudie, T., Scher, J., Tchiégang, C., \& Hardy, J. (2005). Effect of fat sources on the physico-chemical nutritional and textural properties of beef sausages. Journal of Food Technology, 3(2), 220-225.

García, M. L., Cáceres, E., \& Selgas, M. D. (2006). Effect of inulin on the textural and sensory properties of mortadella, a Spanish cooked meat product. International Journal of Food Science \& Technology, 41(10), 1207-1215. http://dx.doi.org/10.1111/j.13652621.2006.01186.x.

García-García, E., \& Totosaus, A. (2008). Low-fat sodium-reduced sausages: Effect of the interaction between locust bean gum, potato starch and $\kappa$-carrageenan by a mixture design approach. Meat Science, 78(4), 406-413. http://dx.doi.org/10.1016/j. meatsci.2007.07.003. PMid:22062459

González-Viñas, M. A., Caballero, A. B., Gallego, I., \& García Ruiz, A. (2004). Evaluation of the physico-chemical, rheological and sensory characteristics of commercially available Frankfurters in Spain and consumer preferences. Meat Science, 67(4), 633-641. http://dx.doi. org/10.1016/j.meatsci.2004.01.004. PMid:22061813

Grizotto, R. K., Andrade, J. C., Miyagusku, L., \& Yamada, E. A. (2012). Physical, chemical, technological and sensory characteristics of Frankfurter type sausage containing okara flour. Ciência e Tecnologia de Alimentos, 32(3), 538-546.

Huang, S. C., Tsai, Y. F., \& Chen, C. M. (2011). Effects of wheat fiber, oat fiber, and inulin on sensory and physico-chemical properties of chinese-style sausages. Asian-Australasian Journal of Animal Sciences, 24(6), 875-880. http://dx.doi.org/10.5713/ajas.2011.10317.

Jiménez-Colmenero, F., Cofrades, S., López-López, I., Ruiz-Capillas, C., Pintado, T., \& Solas, M. T. (2010a). Technological and sensory characteristics of reduced/low-fat, low-salt frankfurters as affected by the addition of konjac and seaweed. Meat Science, 84(3), 356-363. http://dx.doi.org/10.1016/j.meatsci.2009.09.002. PMid:20374797

Jiménez-Colmenero, F., Herrero, A., Pintado, T., Solas, M. T., \& RuizCapillas, D. (2010b). Influence of emulsified olive oil stabilizing system used for pork backfat replacement in frankfurters. Food Research International, 43(8), 2068-2076. http://dx.doi. org/10.1016/j.foodres.2010.06.010.

Kim, I. S., Jin, S. K., Mandal, P. K., \& Kang, S. N. (2011). Quality of low-fat pork sausages with tomato powder as colour and functional additive during refrigerated storage. Journal of Food Science and 
Technology, 48(5), 591-597. http://dx.doi.org/10.1007/s13197-0100182-2. PMid:23572792

López-López, I., Cofrades, S., \& Jiménez-Colmenero, F. (2009). Low-fat frankfurters enriched with n-3 PUFA and edible seaweed: Effects of olive oil and chilled storage on physicochemical, sensory and microbial characteristics. Meat Science, 83(1), 148-154. http:// dx.doi.org/10.1016/j.meatsci.2009.04.014. PMid:20416775

Meilgaard, M., Civille, G. V., \& Carr, T. B. (2006). Affective tests consumer tests and in-house panel acceptance tests. In M. Meilgaard, G. V. Civille \& T. B. Carr, Sensory evaluation techniques (4th ed., cap. 12, pp. 231-251). Boca Raton: CRC Press.

Muguerza, E., Gimeno, O., Ansorena, D., \& Astiasarán, I. (2004). New formulations for healthier dry fermented sausages: a review. Trends in Food Science \& Technology, 15(9), 452-457. http://dx.doi. org/10.1016/j.tifs.2003.12.010.

Nowak, B., Von Mueffling, T., Grotheer, J., Klein, G., \& Watkinson, B. M. (2007). Energy content, sensory properties, and microbiological shelf life of German Bologna-type sausages produced with citrate or phosphate and with inulin as fat replacer. Journal of Food Science, 72(9), S629-S638. http://dx.doi.org/10.1111/j.17503841.2007.00566.x.

Özvural, E. B., Vural, H., Gökbulut, İ., \& Özboy-Özbaş, Ö. (2009). Utilization of brewer's spent grain in the production of Frankfurters. International Journal of Food Science \& Technology, 44(6), 10931099. http://dx.doi.org/10.1111/j.1365-2621.2009.01921.x.

Pereira, A. G. T., Ramos, E. M., Teixeira, J. T., Cardoso, G. P., Ramos, A. L., \& Fontes, P. R. (2011). Effects of the addition of mechanically deboned poultry meat and collagen fibers on quality characteristics of frankfurter-type sausages. Meat Science, 89(4), 519-525. http:// dx.doi.org/10.1016/j.meatsci.2011.05.022. PMid:21669499

Ritzoulis, C., Petridis, D., Derlikis, E. M., Fytianos, K., \& Asteriou, P. (2010). Utilization of inverse water-in-oil emulsions as fat replacers in frankfurter model sausages: influence of fat emulsion content on the organoleptic and mechanical properties. Journal of Texture Studies, 41(1), 62-74. http://dx.doi.org/10.1111/j.17454603.2009.00213.x.

Roberfroid, M. (2007). Prebiotics: the concept revisited. The Journal of Nutrition, 137(3, Suppl. 2), 830S-837S. PMid:17311983.

SAS Institute. (2006). Statistical Analysis System. Version 9.1.3. Cary, North Carolina.
Savadkoohi, S., Hoogenkamp, H., Shamsi, K., \& Farahnaky, A. (2014). Color, sensory and textural attributes of beef frankfurter, beef ham and meat-free sausage containing tomato pomace. Meat Science, 97(4), 410-418. http://dx.doi.org/10.1016/j.meatsci.2014.03.017. PMid:24769097

Su, Y. K., Bowers, J. A., \& Zayas, J. F. (2000). Physical characteristics and microstructure of reduced-fat frankfurters as affected by salt and emulsified fats stabilized with nonmeat proteins. Journal of Food Science, 65(1), 123-128. http://dx.doi.org/10.1111/j.1365-2621.2000. tb15966.x.

Tobin, B. D., O’Sullivan, M. G., Hamill, R. M., \& Kerry, J. P. (2012). Effect of varying salt and fat levels on the sensory and physiochemical quality of frankfurters. Meat Science, 92(4), 659-666. http://dx.doi. org/10.1016/j.meatsci.2012.06.017. PMid:22784420

Totosaus, A., \& Pérez-Chabela, M. L. (2009). Textural properties and microstructure of low-fat and sodium-reduced meat batters formulated with gellan gum and dicatonic salts. LWT-Food Science and Technology, 42(2), 563-569. http://dx.doi.org/10.1016/j. lwt.2008.07.016.

Tsai, T. C., \& Ockerman, H. W. (1981). Water binding measurement of meat. Journal of Food Science, 46(3), 697-701. http://dx.doi. org/10.1111/j.1365-2621.1981.tb15328.x.

Vural, H., Javidipour, I., \& Ozbas, O. O. (2004). Effects of interesterified vegetable oils and sugarbeet fiber on the quality of frankfurters. Meat Science, 67(1), 65-72. http://dx.doi.org/10.1016/j. meatsci.2003.09.006. PMid:22061117

Xiong, Y. L., Noel, D. C., \& Moody, W. G. (1999). Textural and sensory properties of low-fat beef sausages with added water and polysaccharides as affected by $\mathrm{pH}$ and salt. Journal of Food Science, 64(3), 550-554. http://dx.doi.org/10.1111/j.1365-2621.1999. tb15083.x.

Yang, H. S., Choi, S. G., Jeon, J. T., Park, G. B., \& Joo, S. T. (2007). Textural and sensory properties of low fat pork sausages with added hydrated oatmeal and tofu as texture-modifying agents. Meat Science, 75(2), 283-289. http://dx.doi.org/10.1016/j. meatsci.2006.07.013. PMid:22063660

Youssef, M. K., \& Barbut, S. (2011). Effects of two types of soy protein isolates, native and preheated whey protein isolates on emulsified meat batters prepared at different protein levels. Meat Science, 87(1), 54-60. http://dx.doi.org/10.1016/j.meatsci.2010.09.002. PMid:20875930 